\title{
PERAN MEDIA BIMBINGAN BELAJAR ONLINE "RUANGGURU" DALAM PEMBELAJARAN IPA BAGI SISWA SMP DAN SMA MASA KINI: SEBUAH PENGANTAR
}

\author{
Samuel Gideon \\ samuel.gideon@uki.ac.id \\ Universitas Kristen Indonesia
}

\begin{abstract}
Millennial generations, mostly junior and senior high school students are spending much more of their time with gadgets. Nowadays, many students find it hard to understand their school lessons then neglect them at home. Parents realize this problem then help their children by enrolling them in tutoring agencies or seeking private tutors. With the development of $\mathrm{m}$ learning, students no longer need to come to the location of guidance because they can learn whenever they want each they bring a laptop or smartphone by accessing online tutoring. Ruangguru presents as one of alternative online tutoring media can be easily accessed via smartphone, laptop or tablet. Ruangguru provides some excellent features such as RuangUji, RuangLatihan, RuangVideo, RuangLes, RuangLesOnline, DigitalBootCamp dan Edumail allow students to upgrade their learning abilities so that they are expected to achieve the desired results.
\end{abstract}

Key Words: m-learning, ruangguru.

\begin{abstract}
ABSTRAK
Generasi milenial yang sebagian besar merupakan pelajar SMP dan SMA lebih banyak menghabiskan waktunya dengan gadget. Banyak pelajar masa kini sulit memahami pelajaran yang dipelajari di sekolah sehingga sampai di rumah mereka kembali sibuk dengan gadget-nya masingmasing dan melupakan topik pelajaran yang telah dipelajari di sekolah. Oleh karena itu, kebanyakan orangtua menyadari hal tersebut sehingga memberikan pelajaran tambahan bagi anak-anaknya dengan mendaftarkan anak-anaknya ke lembaga-lembaga bimbingan belajar (bimbel) terkenal ataupun mencari guru-guru les privat. Dengan semakin berkembangnya m-learning, siswa tidak perlu lagi harus datang ke lokasi bimbel karena Mereka bisa belajar kapanpun mereka mau setiap mereka membawa laptop atau smartphone dengan mengakses bimbingan belajar online (bimbel online). Ruangguru hadir sebagai salah satu alternatif bimbel online yang dapat dengan mudah diakses melalui smartphone, laptop ataupun tablet. Beberapa fitur unggulan seperti RuangUji,
\end{abstract}


Gideon, Peran Media Bimbingan Belajar Online "Ruangguru" dalam Pembelajaran IPA BAGI Siswa SMP dan SMA Masa Kini: Sebuah Pengantar

RuangLatihan, RuangVideo, RuangLes, RuangLesOnline, DigitalBootCamp dan Edumail memungkinkan siswa untuk meng-upgrade kemampuan belajarnya sehingga diharapkan dapat mencapai hasil yang diinginkan.

Kata Kunci: m-learning, ruangguru.

\section{PENDAHULUAN \\ Latar Belakang}

Pendahuluan memuat tentang permasalahan penelitian, Di abad ke-21 ini, teknologi informasi dan komunikasi (TIK) sudah menjadi hal yang lumrah bagi masyarakat di dunia. Semua informasi dapat diakses dengan mudah seolah-olah informasi itu hanyalah berada di ujung jari. Perkembangan teknologi gadget seperti smartphone dan laptop semakin memudahkan orang memanfaatkan internet untuk mendapatkan semua kebutuhannya secara online. Generasi yang memanfaatkan TIK tersebut seringkali dinamakan dengan generasi milenial.

Wikipedia

mendefinisikan generasi/kaum milenial adalah generasi muda yang terlahir antara tahun 1980an sampai 2000an di mana dunia modern dan teknologi canggih diperkenalkan publik. Indonesia juga tak ketinggalan memiliki generasi milenial. Lembaga riset digital marketing Emarketer memperkirakan pada tahun 2018 jumlah pengguna aktif smartphone di Indonesia lebih dari 100 juta orang yang menempatkan Indonesia sebagai negara pengguna aktif smartphone terbesar keempat di dunia setelah Cina, India, dan Amerika Serikat dengan sedikitnya 49,5 persen pengguna internet berusia 19-34 tahun.

Generasi milenial tersebut seringkali diasosiasikan dengan istilah "kids zaman now". Fredy Manuareng dalam tulisannya menyatakan bahwa istilah " kids zaman now " menggambarkan keadaan anak-anak zaman sekarang. Jika mengaitkan kebiasaan anak-anak zaman sekarang dengan yang sebelumnya, kita akan menemukan hal-hal yang berbeda di situ. Misalnya, gaya hidup yang bergantung pada gadget. Studi yang dilakukan oleh Ericsson hingga 2011 silam hanya ada sekitar 7\% remaja berusia 16 - 19 tahun yang menonton video melalui Youtube. Rata-rata mereka menghabiskan waktu di depan layar perangkat mobile sekitar tiga jam sehari. Angka tersebut melambung sebesar $20 \%$ empat tahun kemudian. Waktu yang dialokasikan untuk menonton streaming juga meningkat tiga kali lipat. Fakta tersebut membuktikan, perilaku generasi millennial sudah tak bisa dilepaskan dari menonton video secara daring. Pada tahun 2016, studi yang dilakukan Nielsen 
Global Survey of E-commerce menggambarkan perilaku generasi milenial yang akrab internet ini memilih jalur online untuk meneliti dan membeli beragam produk atau jasa dalam memenuhi kebutuhan sehari-hari melalui aplikasi-aplikasi digital startup yang memudahkan transportasi seperti Go-Jek, aplikasi untuk ticketing \& traveling Traveloka maupun aplikasi jualbeli seperti Tokopedia. Nielsen mencatat pertumbuhan penetrasi perangkat mobile di kota-kota besar Indonesia mencapai 88 persen.

Generasi milenial yang
sebagian besar merupakan
pelajar SMP dan SMA tersebut lebih banyak menghabiskan waktunya dengan gadget mereka sehingga dapat dikatakan bahwa mereka ketergantungan terhadap teknologi. Bagi mereka, teknologi di genggaman tangan bisa diibaratkan seperti udara dan air. Mereka tidak akan bisa hidup dengan baik jika tidak didampingi teknologi. Mereka merasa kalau teknologi membuat mereka mudah terhubung satu sama lain dan mudah mengakses berbagai informasi penting setiap hari. Hal tersebut pada akhirnya mempengaruhi motivasi belajar mereka di sekolah. Sementara itu, proses belajar mengajar (PBM) di sekolah masih banyak menggunakan model konvensional yang lebih dikenal dengan teacher centered learning (TCL) sehingga model tersebut dirasa membosankan bagi pelajar masa kini. Akibatnya, banyak pelajar masa kini sulit memahami pelajaran yang dipelajari di sekolah dan kemudian sampai di rumah mereka kembali sibuk dengan gadget-nya masingmasing dan melupakan topik pelajaran yang telah dipelajari di sekolah. Oleh karena itu, kebanyakan orangtua menyadari hal tersebut sehingga memberikan pelajaran tambahan bagi anak-anaknya untuk mengakomodasi sekaligus mengharapkan jaminan agar anak-anaknya mendapatkan hasil belajar yang bagus di sekolah. Para orangtua mendaftarkan anak-anaknya ke lembagalembaga bimbingan belajar (bimbel) terkenal ataupun mencari guru-guru les privat dari agen-agen penghubung dan menghabiskan banyak uang dengan harapan bimbel ataupun les privat dapat mendongkrak motivasi maupun hasil belajar anak-anaknya.

\section{Pembelajaran Sains}

Menurut Zubaidah (2011), sains atau yang dalam bahasa Indonesia dikenal dengan nama IImu Pengetahuan Alam (IPA) didefinisikan sebagai pengetahuan yang sistematis dan tersusun secara teratur, berlaku umum (universal) dan berupa kumpulan data hasil observasi dan eksperimen. la menambahkan bahwa sains sebagai pengetahuan yang diperoleh melalui pengumpulan data dengan eksperimen, pengamatan, dan deduksi untuk menghasilkan suatu penjelasan tentang sebuah gejala yang dapat dipercaya. Menurut 
Gideon, Peran Media Bimbingan Belajar Online "Ruangguru" dalam Pembelajaran IPA BAGI Siswa SMP dan SMA Masa Kini: Sebuah Pengantar

Arviansyah dkk (2016) IPA adalah pengetahuan yang mempelajarai tentang femomena alam baik hidup maupun tak hidup yang meliputi tiga bidang ilmu dasar, yaitu Biologi, Fisika dan Kimia. Pada tingkat SD dan SMP siswa diajarkan konsep dasar IPA yang ada di sekitarnya secara utuh, sedangkan saat tingkat SMA siswa diajarkan agar menjadi ahli IPA (Pratiwi \& Muslim, 2015).

Aprianosa (2014) berpendapat bahwa perkembangan ilmu pengetahuan dan teknologi yang sangat cepat mendorong siswa untuk meningkatkan kemampuannya dalam bidang sains sebagai bekal di masa depan. Ali dkk (2013) menyatakan bahwa proses pembelajaran IPA menekankan pada pemberian pengalaman langsung untuk mengembangkan kompetensi agar menjelajahi dan memahami alam sekitar secara ilmiah sehingga diharapkan dapat menjadi wahana bagi peserta didik untuk mempelajari diri sendiri dan alam sekitar, serta prospek pengembangan lebih lanjut dalam menerapkannya di dalam kehidupan sehari-hari. Wenno dkk (2016) menyebutkan bahwa dalam pembelajaran sains, siswa tidak hanya mempelajari sejumlah teori dan prinsip, tetapi juga harus menganalisis bagaimana cara memperoleh fakta dan prinsip tersebut. Pembelajaran sains juga harus mampu membuat siswa memiliki kemampuan untuk mengkonstruksi pengetahuannya sendiri, menggeneralisasikan dan mengaitkan konsep, menganalisis, dan menjawap pertanyaan.

\section{Bimbingan Belajar Tambahan}

Menurut Faizah (2010)

bimbingan belajar adalah suatu

proses pemberian bantuan kepada siswa dalam menyelesaikan masalah-masalah belajar yang dihadapi siswa, sehingga tercapai tujuan belajar yang diinginkan. Menurut Safrudin (2014) bimbingan belajar adalah suatu bantuan kepada siswa dalam memecahkan kesulitan dalam belajar baik di sekolah maupun di luar sekolah. Menurut Tarwiah (2012) bimbingan belajar dijabarkan melalui empat hal yaitu strategi pembelajaran, konsultasi belajar, pemecahan masalah dan evaluasi perkembangan belajar. Thahir dan Hidriyanti (2017) layanan bimbingan yang memungkinkan para peserta didik secara memperoleh berbagai bahan dari narasumber tertentu (terutama dari pembimbing/konselor) yang berguna untuk menunjang kehidupannya sehari-hari baik sebagai individu maupun sebagai pelajar, anggota keluarga dan masyarakat serta untuk pertimbangan dalam pengambilan keputusan.

Berdasarkan wawancara dengan murid-murid SMA yang pernah mengikuti lembaga bimbingan belajar, Novandhika (2013) menyatakan bahwa lembaga bimbingan belajar memiliki perbedaan dengan sekolah. pada umumnya. 
Misalnya, segi durasi kegiatan pembelajaran, lembaga bimbingan belajar memiliki durasi yang lebih pendek daripada sekolah pada umumnya, dan segi pemberian materi juga dapat dilihat perbedaannya. Pada kegiatan belajar, peserta didik diajarkan cara-cara (misalkan saja rumus) yang tidak diajarkan di sekolah, yang notabene lebih mudah dicerna oleh memori peserta didiknya dibandingkan. Suherman (2010) menyatakan bahwa fungsi bimbingan belajar adalah: (1) Fungsi pencegahan (preventive function), yaitu bimbingan belajar berupaya untuk mencegah atau mereduksi kemungkinan timbulnya masalah; (2) Fungsi penyaluran (distributive function) yang berarti menyediakan kesempatan kepada siswa untuk menyalurkan bakat dan minat sehingga mencapai hasil belajar yang sesuai dengan kemampuannya; (3) Fungsi penyesuaian () adjustive function) yaitu membantu siswa untuk menyesuaikan diri dengan lingkungan; (4) Fungsi perbaikan (remedial function) melalui pengajaran remedial (remedial teaching); dan (5) Fungsi pemeliharaan (maintenance and development function) di mana hasil belajar siswa yang dipandang positif harus tetap dipertahankan, atau bahkan harus ditingkatkan agar tidak mengalami kesulitan lagi.

Dari definisi yang diberikan oleh tersebut kita dapat membedakan bahwa bimbingan belajar di sekolah merupakan tugas dari seorang guru dan sifatnya adalah formal sedangkan bimbingan belajar di luar sekolah merupakan bimbingan belajar tambahan yang sifatnya nonformat di mana dapat dilakukan oleh orangtua di rumah ataupun melalui lembaga bimbingan belajar (yang biasa dikenal dengan istilah "bimbel"), kursus maupun les privat Pada awal munculnya, lembaga bimbingan belajar terkenal sebagai lembaga pendidikan yang mengkhususkan diri untuk memberikan pengetahuan bagi siswa kelas tiga SMA yang akan mengikuti ujian masuk Perguruan Tinggi Negeri (PTN). Munculnya lembaga bimbel didorong juga oleh adanya peraturan mengenai ujian untuk masuk ke perguruan tinggi negeri dan perguruan tinggi swasta yang ada di Indonesia. Seiring berjalannya waktu, lembaga bimbel tidak hanya menawarkan jasa bagi siswa kelas tiga SMA saja melainkan juga program-program belajar secara intensif, reguler, dan privat bagi siswa SD, SMP dan SMA untuk semua kelas.

Bimbel adalah suatu tempat yang dibuat khusus untuk membantu siswa dalam mendalami materi pelajaran sekolah. Bimbel biasanya diperuntukkan bagi mereka yang membutuhkan pelajaran tambahan selain di sekolah. Materi yang disajikan di sebuah bimbel biasanya kepanjangan tangan dari materi yang di dapat di sekolah. Bedanya, bimbel lebih menitik beratkan pada trik-trik mengerjakan soal pelajaran 
Gideon, Peran Media Bimbingan Belajar Online "Ruangguru" dalam Pembelajaran IPA BAGI Siswa SMP dan SMA Masa Kini: Sebuah Pengantar

tertentu. Siswa yang masuk ke sebuah bimbel akan selalu disajikan materi pembahasan soal. Dia dibimbing mengerjakan soal dengan cepat. Bimbel cocok bagi siswa yang membutuhkan waktu tambahan di luar pelajaran sekolah dengan titik berat pada soal-soal. Bahasa yang lebih mudah, bimbel tidak memperdulikan proses materi, tapi bagaimana menyelesaikan persoalan.

Kursus adalah tempat khusus untuk melatih skill seseorang. Maka dari itu kursus hanya fokus pada suatu skill. Misalnya, kursus komputer, bahasa Inggris, tata boga, tata busana, mesin dan lain-lain. Karena tujuannya mencetak orang yang mempunyai kemampuan tertentu, kursus berupaya membekali siswanya dengan kemampuan dan teknik. Kursus cocok bagi orang yang berniat menekuni suatu bidang pekerjaan. Lulusan dari suatu lembaga kursus diharapkan mampu bekerja sesuai bidang yang telah ia pelajari. Seseorang dianggap lulus suatu kursus apabila ia telah mampu menyerap kemampuan yang diikuti selama masa pelatihan. Ini ditandai dengan nilai yang tertera dalam ijasah kursus. Les privat adalah cara belajar one on one. Artinya, siswa dan pengajar berhadapan secara langsung dalam suatu pertemuan dengan mempelajari pelajaran tertentu. Les privat bersifat pribadi dan ini merupakan kelebihan dari les privat. Siswa yang mengikuti les privat lebih merasa bebas berekspresi, menanyakan masalah, dan leluasa menerapkan ilmu yang ia pelajari karena ia berhadapan langsung dengan pengajar secara face to face.

Dengan semakin berkembangnya strategi, model dan media pembelajaran, bimbingan belajar di Indonesia berkembang menjadi bimbingan supercamp, bimbel konvensional dan kursus online. Pada bimbel supercamp, peserta tinggal di dalam satu rumah dan melakukan sesi belajar secara intensif setiap hari di dalam periode tertentu. Dalam satu hari, bisa terdapat 3-4 sesi belajar dengan durasi masing-masing 1,5-2 jam. Bahkan, biasanya peserta diajak untuk mengerjakan tryout sebelum memulai belajar pagi. Sifat pembelajarannya yang intensif dan fokus, menjadikan bimbel ini biasanya diperuntukkan bagi pejuang ujian masuk perguruan tinggi. Pada kursus online, penjelasan di depan kelas diganti dengan menonton video materi. Banyak juga tho situs yang menyediakan akses secara cuma-cuma. Namun, murid tidak bisa melakukan konsultasi personal secara langsung dengan mentor pemateri. Di kursus online, murid juga dituntut untuk dapat belajar secara mandiri. Pada bimbel online, kelas terjadi di dalam grup aplikasi online chat. Kompetisi yang terjadi tidak hanya dengan sesama murid di satu kota tertentu, bahkan bisa datang dari seluruh nasional. Hal ini tentunya membuat jaringan pertemanan 
yang diperoleh menjadi lebih luas.

\section{Media Pembelajaran Berbasis Mobile Learning}

Nuryanto (2004)

mengatakan bahwa dalam pembelajaran media hanyalah satu dari empat komponen yang harus ada. Komponen yang lain, yaitu: sumber informasi, informasi dan penerima informasi. Seandainya satu dari empat komponen tersebut tidak ada, maka proses komunikasi tidak mungkin terjadi. Sementara itu, menurut Santyasa (2007), media pembelajaran adalah segala sesuatu yang dapat digunakan untuk menyalurkan pesan (bahan pembelajaran), sehingga dapat merangsang perhatian, minat, pikiran, dan perasaan siswa dalam kegiatan belajar untuk mencapai tujuan belajar.

Aripurnamayana

mendefinisikan mobile learning sebagai suatu fasilitas atau layanan yang memberikan informasi elektronik secara umum kepada pembelajar dan content yang edukasional yang membantu pencapaian pengetahuan tanpa mempermasalahkan lokasi dan waktu. Istilah mobile learning (mlearning) sendiri mengacu kepada penggunaan perangkat IT genggam dan bergerak, seperti PDA, telepon genggam, laptop dan tablet PC, dalam pengajaran dan pembelajaran (Wood dikutip oleh Tamimuddin, 2007). mlearning merupakan pembelajaran yang unik karena pembelajar dapat mengakses materi, arahan dan aplikasi yang berkaitan dengan pembelajaran kapan-pun dan di manapun. Hal ini akan membantu para pembelajar untuk meningkatkan perhatiannya pada materi pembelajaran, membuat para pembelajar meresapi materi pembelajaran serta dapat mendorong motivasi pembelajar untuk terus belajar sepanjang hidup. Lebih lanjut Wood memperkirakan m-learning akan menjadi cukup pesat dan semakin banyak digunakan dalam jangka waktu dekat. Hal ini didukung oleh beberapa faktor antara lain: (1) Gadget yang beredar semakin banyak, murah dan canggih; (2) Pengguna gadget bertumbuh lebih banyak dari pengguna komputer; (3) Perkembangan teknologi wireless/seluler (2G; 2,5G; 3G); dan (4) Tuntutan kebutuhan konsumen. Kehadiran m-learning memang tidak akan bisa menggantikan e-learning (electronic learning) yang biasa apalagi menggantikan pembelajaran dengan tatap muka dalam kelas (Purbasari dkk, 2012). Kehadiran m-learning ini ditujukan sebagai pelengkap pembelajaran yang ada serta memberikan kesempatan pada siswa untuk mempelajari kembali materi yang kurang dikuasai di manapun dan kapanpun. Hal ini tentu dapat memberikan pengalaman yang berbed dalam proses pembelajaran bagi siswa.

\section{Aplikasi Bimbingan Belajar Online}


Gideon, Peran Media Bimbingan Belajar Online "Ruangguru" dalam Pembelajaran IPA BAGI Siswa SMP dan SMA Masa Kini: Sebuah Pengantar

Dengan
berkembangnya makin
siswa tidak perlu lagi harus
datang ke lokasi bimbel dua atau
tiga kali seminggu. Mereka bisa
belajar kapanpun mereka mau
setiap mereka membawa laptop
atau smartphone. Fenomena
tersebut dinamakan dengan
bimbingan belajar online (bimbel
online). Pelajaran yang siswa
dapatkan di sekolah dapat dipelajari lewat bimbel online ini. Kurikulum yang sudah disiapkan oleh pemerintah yang biasanya diaplikasikan di dalam sekolah juga ada di bimbel online. Kini jasa bimbel online semakin marak tidak di Indonesia tetapi juga di seluruh dunia. Maka dari itu, banyak sekali orang-orang yang berinisiatif untuk membuat jasa bimbel online dengan tutor atau guru berkompetensi tinggi serta pengalaman dan jam terbang yang tinggi. Beberapa aplikasi bimbel online yang terkenal di luar negeri bahkan mendunia antara lain Khan Academy, BYJU, Descomplica dan Yuanfudao sedangkan aplikasi online yang popular antara lain adalah quipper video, zenius.net dan ruangguru.

Khan Academy merupakan salah satu jasa bimbel online yang terkenal sedunia. Diinisiasi oleh orang bernama Salman Khan, Khan Academy merupakan jasa bimbel online yang memproduksi video-video pembelajaran lewat laman YouTube. Khan Academy memang merupakan bimbel online gratis, siswa bisa mengakses ribuan video yang berisikan materi-materi

pembelajaran. Khan Academy menyediakan bantuan untuk mata pelajaran mulai dari Matematika, Seni, Ekonomi, Fisika bahkan sampai IImu Komputer. Keunikan dari Khan Academy adalah mereka memiliki misi untuk menyuguhkan pelajaran gratis untuk siapapun dan di manapun. Mereka sudah bekerjasama dengan organisasi seperti NASA, The Museum of Modern Art, California Academy of Sciences hingga MIT.

$$
\text { BYJU adalah aplikasi }
$$

bimbel online yang sangat terkenal di dunia. Didirikan sejak tahun 2011 oleh BYJU Raveendran di Bengaluru, India Selatan, BYJU menjadi sebuah jasa bimbel online di smartphone yang menyuguhkan materi pelajaran untuk siswa kelas 4 hingga kelas 12 (SD-SMA). Fokus dari bimbel online ini adalah matematika dan ilmu pengetahuan. BYJU menjelaskan segala materi pembelajarannya lewat animasi dan ilustrasi yang sangat menyenangkan, seperti gambar dan juga video yang nggak membosankan. Biasanya, video-video pembelajaran mereka berdurasi 15 hingga 20 menit. Sejauh ini, BYJU diperkirakan memiliki 8 juta murid yang belajar melalui jasa bimbel online mereka.

Descomplica merupakan aplikasi bimbel online terbesar di Brasil dan berbahasa Portugis. Mereka menawarkan 15 ribu video pembelajaran dan videovideo live setiap harinya untuk para siswa yang ingin belajar di 
Descomplica. Fitur paling unik dari Descomplica adalah animasi dan ilustrasi dari video serta template situsnya. Warna yang mencolok dan animasi yang nyentrik menyerupai kartun menjadikan Descomplica salah satu bimbel online yang diminati di dunia.

Zenius merupakan salah satu aplikasi pendidikan di Indonesia yang didirikan oleh Sabda PS dan Medy Suharta pada 7 Juli 2007. Zenius menyediakan layanan akses pendidikan dalam format video berbahasa Indonesia yang disajikan baik secara online melalui website (zenius.net) maupun secara offline dengan media CD dan DVD. Beberapa media startup Indonesia menyebutkan bahwa Zenius hadir sebagai bentuk revolusi pendidikan di Indonesia dengan mengedepankan cara berpikir kritis, logis, rasional, dan pengetahuan sains yang terintegrasi terhadap semua pelajar Indonesia. Pada 16-20 Maret 2015, Zenius menjadi satu di antara 12 perusahaan yang mewakili Indonesia dalam acara CeBIT 2015, sebuah pameran teknologi terbesar di dunia yang diselenggarakan setiap tahun di Jerman.

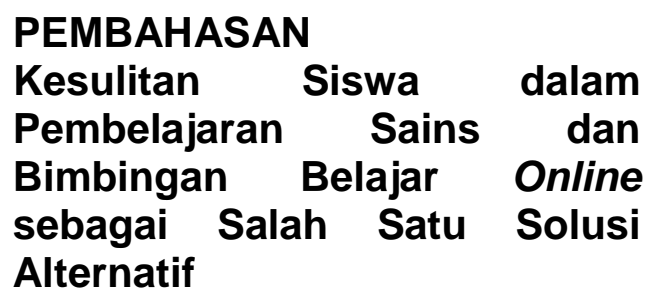

Dari hasil observasi yang dilakukan oleh Arviansyah dkk (2016), permasalahan umum di dalam pembelajaran IPA di SMP yang sering dijumpai adalah kurangnya minat siswa dalam mengikuti pembelajaran dan berdasarkan hasil wawancara mereka terlihat bahwa sebagian besar siswa mengatakan mata pelajaran IPA sulit dipahami dan terlalu banyak berisi rumus-rumus metematis. Hal itu dapat disebabkan kurangnya kreativitas guru dalam menyajikan materi ajar sehingga siswa mudah merasa bosan dalam proses pembelajaran serta guru kurang tepat memilih model pembelajaran sehingga dapat mempengaruhi hasil belajar dan aktivitas belajar siswa. Hamalik sebagaimana dikutip oleh Wenno dkk (2016) menyatakan bahwa jika siswa mengalami kegagalan atau kemunduran dalam hasil belajar, hal itu berarti ada kesulitan yang dihadapi selama pembelajaran. Salah satu indikator kesulitan belajar siswa dapat terlihat dari rendahnya hasil belajar yang diperoleh atau tidak sesuai dengan yang diharapkan. Para guru terkadang kurang memahami setiap kesulitan yang dialami oleh siswa. Padahal, dengan mengetahui kesulitan yang dihadapi oleh siswa dalam pembelajaran, guru dapat mencari solusi atau alternatif pemecahan masalah yang sesuai untuk mengatasi kesulitan yang dihadapi siswa dalam pembelajaran khususnya pembelajaran sains 
Gideon, Peran Media Bimbingan Belajar Online "Ruangguru" dalam Pembelajaran IPA BAGI Siswa SMP dan SMA Masa Kini: Sebuah Pengantar

Tim Jurusan Psikologi Pendidikan (Mulyadi, 2010) mendefinisikan bimbingan belajar sebagai proses pemberian bantuan kepada siswa dalam memecahkan kesulitan-kesulitan yang berhubungan dengan masalah belajar. Proses Belajar Mengajar (PBM) di dalam kelas sangat dibatasi oleh ruang dan waktu, oleh karena itu untuk mengembangkan potensi dan menanamkan kognitif, afektif dan psikomotor secara meyakinkan tidak cukup hanya dengan PBM di dalam kelas. Oleh karena itu kita harus mengembangkan PBM di luar kelas salah satunya dengan memberikan bimbingan belajar (bimbel) tambahan.

Seperti yang telah dibahas di bagian sebelumnya bahwa bimbel dapat berupa bimbel supercamp, bimbel konvensional dan bimbel/kursus online. Bimbel konvensional sudah eksis terlebih dahulu untuk memfasilitasi siswa yang merasa kesulitan dalam memahami materi di sekolah. Jumlah siswa yang mencapai jutaan di seluruh Indonesia tentu tidak sebanding dengan jumlah bimbel konvensional yang ada. Terlebih lagi, biasanya bimbel konvensional menetapkan jumlah maksimal peserta pada tiap ruangan. Hal inilah kemudian yang dilirik oleh bimbel online sebagai potensi bisnis yang memiliki peluang cukup tinggi. Sistem online yang dianut memungkinkan siapapun dapat bergabung dengan bimbingan belajar online tanpa harus khawatir berdesakan dalam ruang kelas. Selama murid memiliki gadget dan jaringan internet yang memadai, ia dapat mengakses bimbingan belajar online di mana pun dan kapanpun.

Setiap

bimbel konvensional akan memberikan siswa materi dan modul yang sesuai dengan tingkat pendidikan siswa yang bersangkutan. Kelemahan dari sistem seperti ini adalah siswa memang akan menerima penjelasan dari para mentor di dalam kelas namun siswa tidak akan bisa mengulang apa yang mentor-mentor tersebut sampaikan kecuali siswa tersebut merekam penjelasan mereka. Seementara itu, dengan sistem online pada bimbel online memungkinkan siswa untuk dapat mengulang materi yang diberikan.

Seiring dengan berjalannya waktu, harga-harga berbagai kebutuhan sepertinya semakin naik-tidak terkecuali bimbel konvensional. Range harga yang ditawarkan biasanya mencapai 2-15 juta rupiah. Harga tersebut bisa mengalami peningkatan, tergantung program les apa yang diambil. Biasanya, bimbel konvensional memiliki program khusus masuk universitas negeri tertentu dengan jaminan pengembalian uang. Hal itulah yang menyebabkan mahalnya harga bimbel konvensional. Bimbel online memberikan solusi dengan opsi pembelajaran yang jauh lebih murah. Sebagai contoh, pada aplikasi bimbel online Quipper, siswa akan mendapatkan materi dari 10 
mata pelajaran dengan total waktu pembelajaran 220 jam dan dapat diakses kapanpun dan di mana pun.

\section{Aplikasi Bimbingan Belajar Online Ruangguru}

Ruangguru merupakan perusahaan teknologi terbesar dan terlengkap di Indonesia yang berfokus pada layanan berbasis pendidikan dan telah memiliki lebih dari 6 juta pengguna serta telah mengelola lebih dari 150.000 guru yang menawarkan jasa di lebih dari 100 bidang pelajaran. Perusahaan ini didirikan sejak tahun 2014 oleh Belva Devara dan Iman Usman, yang keduanya berhasil masuk dalam jajaran pengusaha sukses dibawah 30 tahun melalui Forbes 30 under 30 untuk teknologi konsumen di Asia. Ruangguru adalah perusahaan penyedia layanan pendidikan berbasis teknologi berbasis learning management system yang memungkinkan berbagai pemangku kepentingan di bidang pendidikan yaitu guru, siswa, pemerintah pusat dan daerah serta orang tua siswa untuk saling berinteraksi di dalam suatu platform digital komprehensif, yang telah mencakup lebih dari $2,000,000$ siswa dan guru.

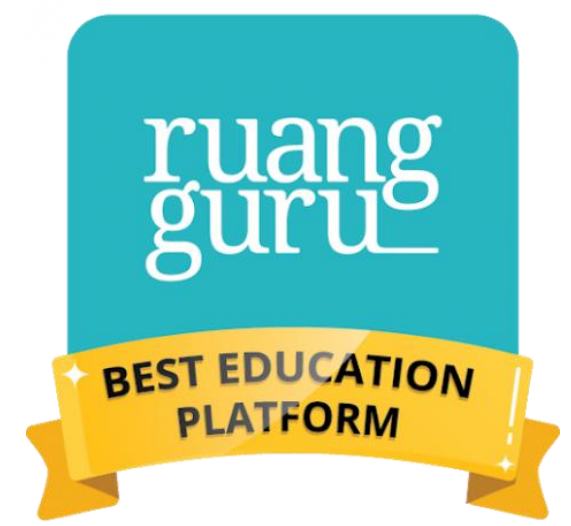

Gambar 1. Simbol aplikasi

Ruangguru (sumber: Ruangguru welcome pack, 2018)

Ruangguru menyediakan beberapa fitur menarik seperti RuangUji, RuangVideo, RuangLatihan, RuangLesOnline, DigitalBootCamp dan Edumail. RuangUji membantu siswa untuk mempersiapkan diri menghadapi ujian semester, ujian nasional, dan Seleksi Bersama Masuk Perguruan Tinggi Negeri (SBMPTN), serta guru dalam menghadapi Uji Kompetensi Guru. RuangUji disertai dengan papan peringkat, pembahasan serta analisis topik sehingga dapat memberikan evaluasi yang komprehensif bagi pengguna. Konten Ruanguji disusun oleh guru-guru yang berkualitas dan tentunya telah disesuaikan dengan standar nasional.

Ruangguru menyediakan beberapa fitur menarik seperti RuangUji, RuangVideo, RuangLatihan, RuangLesOnline, RuangLes, DigitalBootCamp dan Edumail. RuangUji membantu siswa untuk mempersiapkan diri menghadapi ujian semester, ujian nasional, dan Seleksi Bersama Masuk 
Gideon, Peran Media Bimbingan Belajar Online "Ruangguru" dalam Pembelajaran IPA BAGI Siswa SMP dan SMA Masa Kini: Sebuah Pengantar

Perguruan Tinggi Negeri (SBMPTN), serta guru dalam menghadapi Uji Kompetensi Guru.

RuangUji disertai dengan papan peringkat, pembahasan serta analisis topik sehingga dapat memberikan evaluasi yang komprehensif bagi pengguna. Konten Ruanguji disusun oleh guru-guru yang berkualitas dan tentunya telah disesuaikan dengan standar nasional.

RuangLatihan

memudahkan siswa untuk mengerjakan latihan soal dari berbagai subjek dan topik,serta dilengkapi dengan sistem analisis dan gamifikasi sehingga proses latihan menjadi lebih menarik. Terdapat lebih dari 50,000 bank soal yang bisa diakses secara mudah dan gratis oleh siswa dari berbagai jenjang (SD, SMP hingga SMA) melalui aplikasi maupun website. Melalui sistem gamifikasi, RuangLatihan memiliki keunggulan dalam memotivasi siswa untuk melatih dan mengasah kemampuan diri secara terus-menerus.

RuangVideo

memungkinkan mendapatkan siswa belajar yang seru melalui ribuan video konsep dan pembahasan soal sesuai jenjang pendidikan.

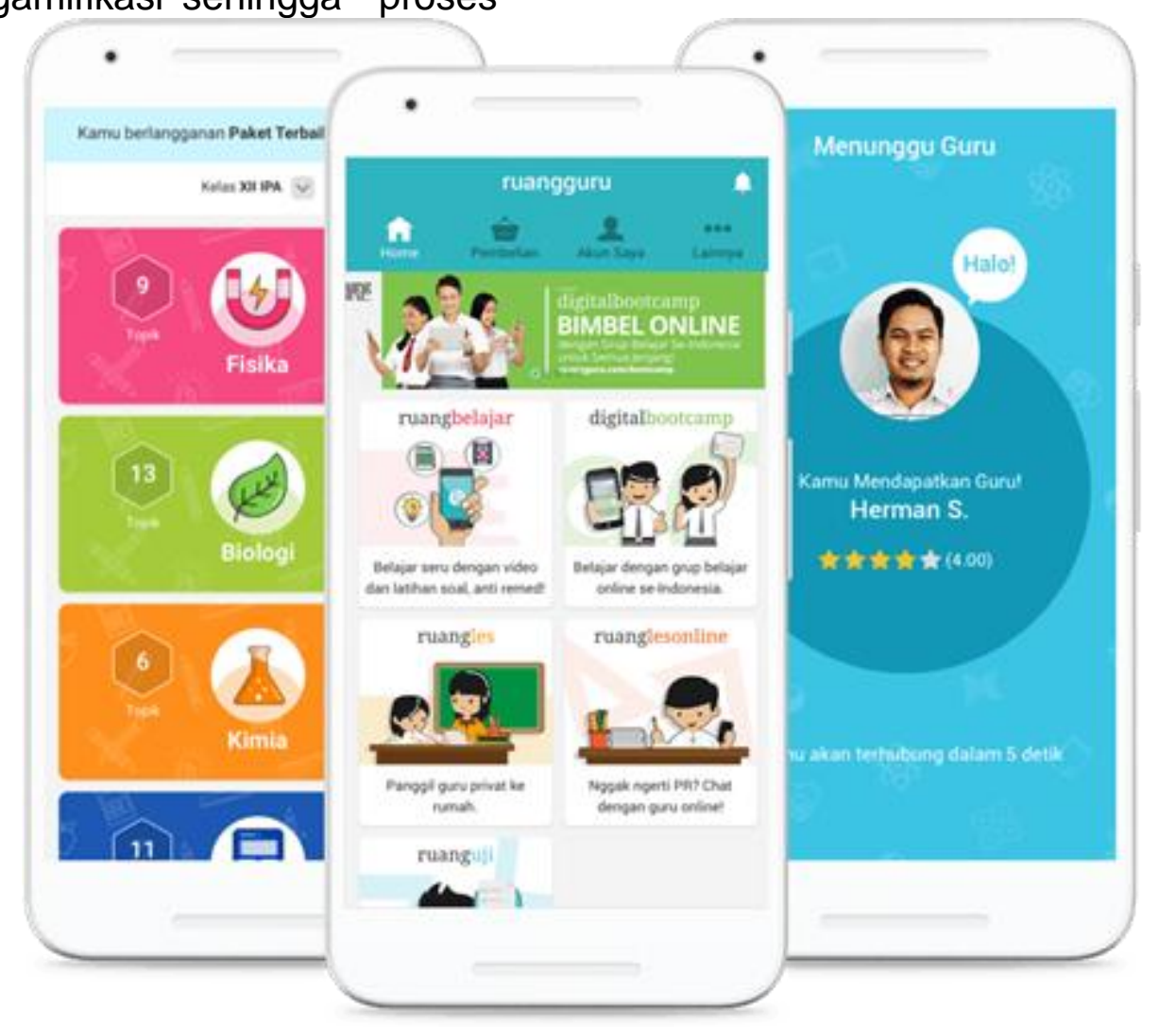

Gambar 2. Tampilan aplikasi Ruangguru (sumber: Ruangguru welcome pack, 2018)

RuangLes merupakan fitur yang menyediakan layanan guruguru privat terbaik ke rumah untuk meningkatkan pemahaman siswa. RuangLesOnline merupakan fitur 
memungkinkan bagi siswa untuk konsultasi belajar secara online melalui smartphone mereka. Siswa dapat memfoto soal-soal sulit yang mereka hadapi kemudian mendiskusikannya (chat online) dengan tutor melalui fitur RuangLesOnline tersebut.

Edumail adalah program kerjasama Telkom bersama Ruangguru dengan membuatkan email gratis bagi pengguna ruangguru yang tidak mempunyai email sehingga pengguna bisa menggunakan layanan Ruangguru secara penuh seperti berlangganan ribuan video belajar dan membeli token untuk bertanya langsung pada guru.

\section{KESIMPULAN DAN SARAN}

Generasi milenial yang sebagian besar merupakan pelajar SMP dan SMA tersebut lebih banyak menghabiskan waktunya dengan gadget. Banyak pelajar masa kini sulit memahami pelajaran yang dipelajari di sekolah dan kemudian sampai di rumah mereka kembali sibuk dengan gadget-nya masing-masing dan melupakan topik pelajaran yang telah dipelajari di sekolah. Oleh karena itu, kebanyakan orangtua menyadari hal tersebut sehingga memberikan pelajaran tambahan bagi anak-anaknya dengan

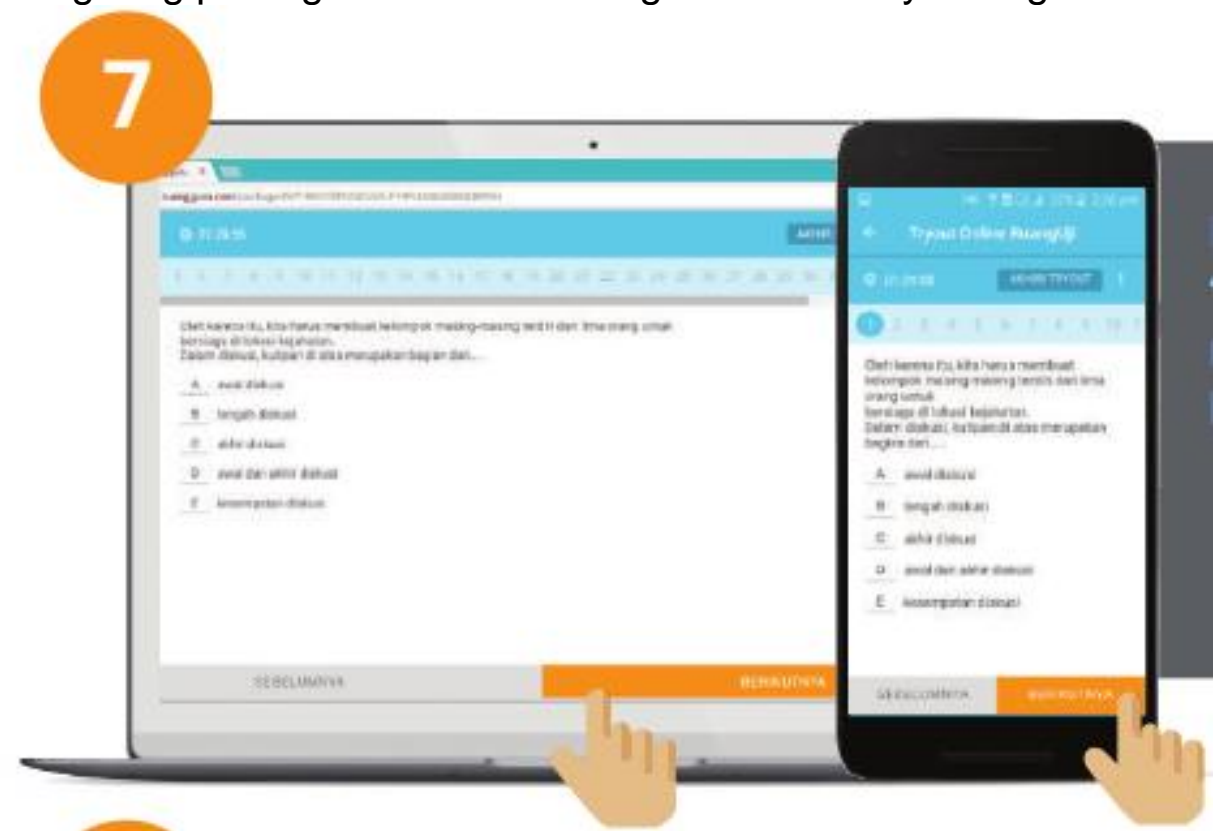

\section{Gambar 3 Tampilan fitur RuangLatihan pada aplikasi Ruangguru (sumber: Ruangguru welcome pack, 2018)}

mendaftarkan anakanaknya ke lembaga-lembaga bimbingan belajar (bimbel) terkenal ataupun mencari guruguru les privat. Dengan semakin berkembangnya m-learning, siswa tidak perlu lagi harus datang ke lokasi bimbel karena Mereka bisa belajar kapanpun mereka mau setiap mereka membawa laptop atau smartphone dengan mengakses bimbingan belajar online (bimbel online). Ruangguru hadir sebagai 
Gideon, Peran Media Bimbingan Belajar Online "Ruangguru" dalam Pembelajaran IPA BAGI Siswa SMP dan SMA Masa Kini: Sebuah Pengantar

salah satu alternatif bimbel online yang dapat dengan mudah diakses melalui smartphone, laptop ataupun tablet. Beberapa fitur unggulan seperti RuangUji, RuangLatihan, RuangVideo, RuangLes, RuangLesOnline, DigitalBootCamp dan Edumail memungkinkan siswa untuk meng-upgrade kemampuan belajarnya sehingga diharapkan dapat mencapai hasil yang diinginkan.

\section{ACUAN PUSTAKA}

Ali, L.U., Suastra, W. \& Sudiatmika, A.A.I.A.R. (2013). Pengelolaan Pembelajaran Ipa Ditinjau dari Hakikat Sains Pada SMP di Kabupaten Lombok Timur. Jurnal Pendidikan IPA, Universitas Pendidikan Ganesha, Vol.3, No.1

Aripurnamayana, M.I. (2012). Rancangan dan Pembuatan Mobile Learning Berbasis Android (Studi Kasus: Pembelajaran Sejarah di SMP). http://jurnalonline.um.ac.id/data/artikel/arti kel2C484B69ABB15E406034 2947D84D09F8.pdf

Arviansyah, R., Indrawati. \& Harijanto, A. (2016). Pengaruh Model Pembelajaran Guided Inquiry Disertai LKS Audiovisual terhadap Aktivitas dan Hasil Belajar IPA Siswa di SMP. Jurnal Pembelajaran Fisika, Universitas Jember, Vol.4, No.4, Hal.309
Faizah, N. (2010). Bimbingan Belajar dalam Meningkatkan Prestasi (Studi di Panti Asuhan Yatim Putra Islam Berbah Kabupaten Sleman Propinsi Daerah Istimiewa Yogyakarta). Skripsi, Universitas Islam Negeri Sunan Kalijaga Yogyakarta

Mulyadi, H (2010). Diagnosis Kesulitan Belajar dan Bimbingan terhadap Kesulitan Belajar Khusus. Cetakan Pertama. Nuha Litera, Jakarta

Novandhika, Y.P. (2013). Lembaga Bimbingan Belajar (LBB) sebagai Penambah Modal Budaya bagi Siswa SMA Kelas XII (Studi Kasus pada LBB Quantum Xcellensia Surabaya). Journal, Universitas Airlangga, Vol.3, No.3, Hal.4

Pratiwi, T.R. \& Muslim (2015). Pembelajaran IPA Terpadu Tipe Integrated Konsep Perubahan untuk Meningkatkan Sikap IImiah Siswa SMP. Prosiding Simposium Nasional Inovasi dan Pembelajaran Sains 2015 (SNIPS 2015)

Purbasari, R.J., Kahfi, M.S. \& Yunus, M. (2012). Pengembangan Aplikasi Android sebagai Media Pembelajaran Matematika pada Materi Dimensi Tiga untuk Siswa SMA Kelas X. Jurnal Online Pendidikan Matematika Universitas Negeri Semarang, Vol.1, No.2 
Ruangguru Welcome Pack (2018).

https://smkalistiqomahcrbn.sc h.id/wpcontent/uploads/2017/10/Petu njuk-Penggunaan-ProdukRuangguru.compressed.pdf

Safrudin, H. (2014). Pengaruh Pelayanan Bimbingan Belajar terhadap Motivasi Belajar Siswa. Jurnal IImiah Pendidikan dan Bimbingan Konseling, IKIP Veteran Semarang, Vol.2, No.1, Hal.63

Santyasa, I.W. (2007). Landasan Konseptual Media Pembelajaran. Makalah disajikan dalam Workshop Media Pembelajaran bagi Guru-Guru SMA Negeri Banjar Angkan

Suherman (2010). Bimbingan Belajar.

file.upi.edu/Direktori/FIP/JUR.. .PEND...SUHERMAN/Bimbing an_Belajar.pdf

Tamimuddin,

M. (2007).

Pengenalan Media

Pembelajaran Berbasis Mobile (Mobile Learning). PPPPTK Matematika

Tarwiah, V.J. (2012). Pengaruh Bimbingan Belajar dalam Meningkatkan Prestasi Belajar Peserta Didik Kelas VIII Mts Negeri Godean, Sleman, Yogyakarta. Skripsi, Universitas Islam Negeri Sunan Kalijaga Yogyakarta
Thahir, A. \& Indiyanti, B. (2017). Pengaruh Bimbingan Belajar terhadap Prestasi Belajar Siswa Pondok Pesantren Madrasah Aliyah Al-Utrujiyyah Kota Karang Bandar Lampung. Jurnal Bimbingan dan Konseling (E-Journal), Universitas Islam Negeri Raden Inten Lampung, Vol.1, No.2, Hal.2

Wenno, I.H., Esomar, K. \& Sopacua, V. (2016). Analisis Kesulitan Belajar dan Pencapaian Hasil Belajar Siswa melalui Strategi Pembelajaran Inkuiri. Cakrawala Pendidikan Jurnal IImiah Pendidikan, Universitas Negeri Yogyakarta, Vol.2, No.3, Hal.379

Yayan, Yulianto. (2012) Media Pembelajaran sebagai Alat Bantu Dalam Meningkatkan Suatu Proses dan Hasil Pembelajaran. Skripsi, Universitas Negeri Yogyakarta

$\begin{array}{lr}\text { Zubaidah, S. } & \text { (2011). } \\ \text { PEMBELAJARAN SAINS } \\ \text { (IPA) SEBAGAI WAHANA } \\ \text { PENDIDIKAN KARAKTER. } \\ \text { Makalah disajikan pada } \\ \text { Seminar Nasional II } \\ \text { "Mewujudkan Pendidik dan } \\ \text { Tenaga kependidikan yang } \\ \text { Profesional" Pekanbaru. }\end{array}$

http://salamsatudata.web.id/kursu s-online/kekurangan-dankelebihan-ruangguru-quipperdan-zenius, diakses pada tanggal 17 Juli 2018 pukul 11.45 WIB 
Gideon, Peran Media Bimbingan Belajar Online "Ruangguru" dalam Pembelajaran IPA BAGI Siswa SMP dan SMA Masa Kini: Sebuah Pengantar

http://ismyama.com/ruanggurudan-quipper-mediabimbingan-belajar-online/, diakses pada tanggal 17 Juli 2018 pukul 14.15 WIB

https://www.sandraartsense.com/ 2017/10/antara-ruanggurudan-quipper-manakah.html, diakses pada tanggal 18 Juli 2018 pukul 16.42 WIB

https://www.tianlustiana.com/201 7/10/banyak-banget-pilihanles-privat-online.html, diakses pada tanggal 19 Juli 2018 pukul 10.16 WIB

https://www.parentian.com/2017/

10/bingung-pilih-quipper-atauruangguru.html, diakses pada tanggal 19 Juli pukul 2018 11.12 WIB

https://catatanskyva.wordpress.co $\mathrm{m} / 2017 / 10 / 25 /$ bimbel-yangcocok-buat-kamu/, diakses pada tanggal 20 Juli 2018 pukul 10.19 WIB

https://www.bukalapak.com/blog/t echnology/5-aplikasi-belajaronline-di-smartphone-yangbisa-kamu-coba-4575, diakses pada tanggal 24 Juli 2018 pukul 14.12 WIB https://blog.ruangguru.com/5-tipebimbingan-belajar-diindonesia, diakses pada tanggal 24 Juli 2018 pukul 15.00 WIB

https://www.bukalapak.com/blog/t echnology/5-aplikasi-belajaronline-di-smartphone-yangbisa-kamu-coba-4575, diakses pada tanggal 24 Juli 2018 pukul 15.20 WIB

https://www.quipper.com/id/blog/ti ps-trick/bimbel-guide/10rekomendasi-bimbel-onlinekelas-dunia-yang-harus-kamutahu/, diakses pada tanggal 24 Juli 2018 pukul 16.20 WIB

http://majalah1000guru.net/2016/ 08/gaya-belajar-generasi-z/, diakses pada tanggal 24 Juli 2018 pukul 17.05 WIB

http://www.sekolahoke.com/2011/ 04/bedanya-bimbel-kursusdan-les-privat.html, diakses pada tanggal 24 Juli 2018 pukul 17.32 WIB 